\title{
HUBUNGAN PELAKSANAAN TUGAS KELUARGA DALAM KESEHATAN DENGAN KEMANDIRIAN LANSIA DALAM PEMENUHAN AKTIVITAS SEHARI-HARI
}

\author{
Ahsan, Kumboyono, Melida Nur Faizah \\ Fakultas Keperawatan Fakultas Kedokteran Universitas Brawijaya Malang \\ Jl. Veteran Malang Jawa Timur \\ Email : ahsanfkub@yahoo.com
}

\begin{abstract}
Physical changes make elderly limited in performing activities of daily living (ADL) and tend to depend on the family cause the closest has an important role in maintaining the health of the elderly. It can be seen from the implementation of family task in health. The purpose of this study was to determine the correlation implementation of family task in health with independence of elderly in ADL compliance using cross sectional method. Samples were selected by purposive sampling technique with the inclusion criteria and obtained a sample of 40 people. The results showed the number of families who carry out the task of the family in good health with the independence of the elderly category independent category as many as 22 people (55\%). While on a family who carry out tasks in the family health category with the independence of the elderly poor are as many categories 1 (2.5\%). Based on using the Spearman rank test p-value $0.000<0.05$, which means there is a very strong correlation between the two variables. In addition, because the correlation coefficient 0.817 and the results obtained are positive, so we can conclude that the relationship between the two variables is the direction in which the better execution of tasks in the family health, the higher the independence of the elderly in meeting the $A D L$.
\end{abstract}

Keywords : family, family task, elderly, ADL independence

Abstrak : Perubahan fisik menjadikan lansia terbatas dalam melakukan activity of daily living (ADL) dan cenderung tergantung keluarga karena paling dekat sehingga berperan penting dalam menjaga kesehatan lansia. Hal ini dapat dilihat dari pelaksanaan tugas keluarga dalam kesehatan. Tujuan penelitian ini adalah mengetahui hubungan pelaksanaan tugas keluarga dalam kesehatan dengan kemandirian lansia dalam pemenuhan ADL dengan menggunakan metode cross sectional. Sampel dipilih dengan teknik purposive sampling dengan kriteria inklusi dan didapatkan sampel sejumlah 40 orang. Hasil penelitian didapatkan jumlah keluarga yang melaksanakan tugas keluarga dalam kesehatan kategori baik dengan kemandirian lansia kategori mandiri sebanyak 22 orang (55\%). Sedangkan pada keluarga yang melaksanakan tugas keluarga dalam kesehatan kategori kurang baik dengan kemandirian lansia kategori sedang sebanyak 1 orang $(2,5 \%)$. Berdasarkan uji rank spearman menggunakan $p$-value $0,000<0,05$, berarti ada hubungan yang sangat kuat antara dua variabel. Selain itu, karena koefisien korelasi didapatkan hasil 0,817 dan bernilai positif, jadi dapat disimpulkan bahwa hubungan antara kedua variabel adalah searah dimana semakin baik pelaksanaan tugas keluarga dalam kesehatan, semakin tinggi kemandirian lansia dalam memenuhi ADL.

Kata kunci: keluarga, tugas keluarga, lansia, kemandirian ADL

\section{PENDAHULUAN}

Pemerintah Indonesia telah mewujudkan hasil yang positif dalam berbagai bidang pembangunan nasional, yaitu adanya kemajuan ekonomi, perbaikan lingkungan hidup, kemajuan ilmu pengetahuan dan teknologi, terutama di bidang kesehatan sehingga dapat meningkatkan kualitas kesehatan penduduk. Melihat kualitas penduduk meningkat, maka angka umur harapan hidup manusia juga meningkat. Hal tersebut mengakibatkan jumlah penduduk yang berusia lanjut terus meningkat dan bertambah cenderung lebih cepat (Bandiyah, 2009). Secara umum, populasi penduduk usia lanjut di negara-negara dunia diprediksi akan mengalami peningkatan. Populasi usia lanjut di seluruh dunia pada tahun 2006 diperkirakan mencapai 500 juta dengan usia rata-rata 60 tahun dan diperkirakan pada tahun 2025 akan mencapai 1,2 milyar (Bandiyah, 2009). Data dari Badan Pusat Statistik memprediksikan bahwa persentase penduduk lanjut usia di Indonesia akan mencapai $9,77 \%$ dari total penduduk Indonesia pada tahun 2010 dan menjadi $11,34 \%$ pada tahun 2020 (Maryam, 2008). Sedangkan persentase penduduk lanjut usia di Jawa Timur pada tahun 2010 diperkirakan mencapai $10,40 \%$ dari total penduduk di Jawa Timur (Primadi, 2013). Menurut Dinas Kesehatan Kabupaten Nganjuk jumlah lansia di Kabupaten Nganjuk sekitar 463.365 lansia pada tahun 2012. Berdasarkan 
hasil studi pendahuluan di Dusun Bendungrejo Desa Bendungrejo Kecamatan Berbek Kabupaten Nganjuk jumlah lansia di dusun tersebut sekitar 44 lansia.

Proses menua senantiasa disertai dengan perubahan di semua sistem didalam tubuh manusia. Perubahan di semua sistem di dalam tubuh manusia tersebut salah satu misalnya terdapat pada sistem saraf. Perubahan tersebut dapat mengakibatkan terjadinya penurunan dari fungsi kerja otak (Fatmah, 2010). Penelitian terkini menyebutkan bahwa walaupun tanpa adanya penyakit neurodegeneratif, jelas terdapat perubahan struktur otak manusia seiring bertambahnya usia. Serta, perubahan patologis pada serebrovaskular juga berhubungan dengan kemunduran fungsi kognitif (Kuczynski, 2009).

Kemunduran yang dialami lansia tersebut akan membawa implikasi pada berbagai aspek kehidupan, baik berkeluarga maupun bermasyarakat. Salah satunya adalah masalah yang berkaitan dengan kehidupan lansia, yaitu beban ketergantungan (dependency ratio) yang semakin besar. Setiap penduduk usia produktif akan menanggung semakin banyak penduduk usia lanjut. Suhartini (2009) memperkirakan angka ketergantungan usia lanjut pada tahun 1995 adalah $6,93 \%$ dan tahun 2015 menjadi 8,74\%, ini artinya pada pada tahun 1995 sebanyak 100 penduduk produktif harus menyokong 7 orang usia lanjut yang berumur 65 tahun keatas sedangkan pada tahun 2015 sebanyak 100 penduduk produktif harus menyokong 9 orang lanjut usia yang berumur 65 tahun keatas.

Ketergantungan lanjut usia yang paling nyata terlihat pada penurunan dalam memenuhi aktivitas kehidupan sehari-hari secara mandiri. Pemenuhan aktivitas kehidupan sehari-hari pada usia lanjut di bagi menjadi dua yaitu usia lanjut yang masih aktif dan usia lanjut yang pasif sehingga dalam pemenuhan aktivitas sehari-hari tidak dapat dilakukan sendiri tetapi juga harus melibatkan anggota keluarga dan tim kesehatan lainnya. Dalam keadaan ini, keluarga memegang peranan penting dalam pemenuhan aktivitas sehari-hari orang usia lanjut (S.Tamher, 2009).

Keluarga merupakan konteks sosial primer untuk promosi kesehatan dan pencegahan penyakit (Potter \& Perry, 2009). Keluarga bertindak sebagai yang pertama sekali mengenal adanya gangguan kesehatan pada salah satu anggota keluarga. Dalam memelihara kesehatan anggota keluarga (lansia), keluarga sebagai individu (klien) tetap berperan dalam melakukan peran sebagai anggota keluarga. Peran yang dapat dilakukan oleh anggota keluarga dalam menjalankan tugas kesehatan keluarga terhadap lansia, seperti mengenali masalah kesehatan pada lansia, membuat keputusan tindakan kesehatan yang tepat, memberi perawatan pada lansia, mempertahankan suasana rumah yang sehat, serta menggunakan fasilitas kesehatan yang ada (Friedman, 1998 dalam Mubarak, dkk 2006).

Hasil studi pendahuluan yang dilakukan terhadap 5 lansia pada bulan November 2014 di Dusun Bendungrejo, Desa Bendungrejo, Kecamatan Berbek, Kabupaten Nganjuk menyatakan kurang mendapat perhatian dari keluarga, sedangkan 4 dari 5 lansia mengatakan memerlukan bantuan orang lain dalam melakukan aktivitas sehari-hari. Hal tersebut membuktikan lansia mengalami penurunan atau ketergantungan dalam pemenuhan aktivitas sehari-hari.

Kesanggupan keluarga dalam melaksanakan perawatan atau pemeliharaan kesehatan dapat dilihat dari tugas keluarga dapat meningkatkan kualitas hidup lansia yang akan berimplikasi pada kemandirian dalam pemenuhan aktivitas sehari-hari (Mubarak, dkk., 2006). Sehubungan dengan hal tersebut maka peneliti ingin mengetahui hubungan pelakanaan tugas keluarga dalam kesehatan dengan kemandirian lansia dalam pemenuhan aktivitas sehari-hari.

\section{METODE PENELITIAN}

Penelitian ini menggunakan desain analitik cross sectional dengan populasi 44 keluarga lansia di Dusun Bendungrejo, Desa Bendungrejo Kecamatan Berbek, Kabupaten Nganjuk. Sampel adalah keluarga lansia yang berusia 18-59 tahun di sejumlah 40 keluarga dan memenuhi kriteria inklusi. Teknik sampling purposive sampling dengan kriteria inklusi keluarga yang tinggal satu rumah dengan lansia yang berusia 18-59 tahun dan bersedia menjadi responden. Penelitian ini dilaksanakan pada tanggal 5 sampai 11 Februari 2015.

Variabel Independen dalam penelitian ini adalah pelaksanaan tugas keluarga dalam kesehatan sedangkan variabel dependen adalah kemandirian lansia dalam ADL. Instrumen yang digunakan untuk mengukur pelaksanaan tugas keluarga dalam kesehatan adalah kuesioner yang telah dibuat oleh peneliti terdiri dari 30 pertanyaan. Instrumen sebelumnya telah dilakukan uji validitas dan reliabilitas. Setiap pertanyaan diberikan pilihan jawaban dan nilai yaitu, selalu (SL) nilainya 3, sering $(\mathrm{SL})$ nilainya 2 , kadang-kadang $(\mathrm{KK})$ nilainya 1 , dan tidak pernah (TP) nilainya 0 . Sehingga, skor tertinggi adalah 90, dan terendah adalah 0 . Untuk pelaksanaan baik jika skor 61-90, pelaksanaan cukup jika skornya 31-60, pelaksanaan kurang baik jika 
skornya 0-30. Sedangkan kemandirian lansia diukur dengan menggunakan kuesioner indeks katz yang terdiri dari 6 item yaitu mandi, berpakaian, ke toilet, berpindah, kontrol BAB \& BAK, dan makan. Setiap item diberikan nilai 1 jika bisa melakukan secara mandiri, dan diberi nilai 0 jika tidak bisa melakukan sendiri sehingga skor tertinggi 6 , skor terendah 0 . Untuk kategori mandiri jika skornya 6-4, kategori sedang jika skornya 1-3, dan kategori bantuan total jika skornya 0 . Proses pengumpulan data dengan memperhatikan etik penelitian yaitu respect for person, benefence \& non maleficence dan justice. Data yang diperoleh selanjutnya dianalisa dengan menggunakan uji korelasi Rank Spearman dengan $p<0,005$.

\section{HASIL PENELITIAN}

Distribusi data demografi responden pada penelitian ini meliputi usia, jenis kelamin, pendidikan terakhir, pekerjaan dan usia lansia yang disajikan dalam bentuk tabel sebagai berikut :Karakteristik Responden Di Dusun Bendungrejo Desa Bendungrejo Kecamatan Berbek Kabupaten Nganjuk Tahun 2015 yaitu karakteristik usia responden, sebagian besar adalah usia dewasa tengah (40-59 tahun) yaitu sebanyak 23 orang $(57,5 \%)$. Jenis kelamin terbanyak adalah perempuan $(87,5 \%)$, tingkat pendidikan terakhir terbanyak yaitu lulus SMA $(55 \%)$. Sedangkan untuk pekerjaan terbanyak adalah tidak bekerja $(42,5 \%)$. Usia lansia terbanyak adalah pada rentang usia 60-75 tahun sebanyak $(77,5 \%)$.

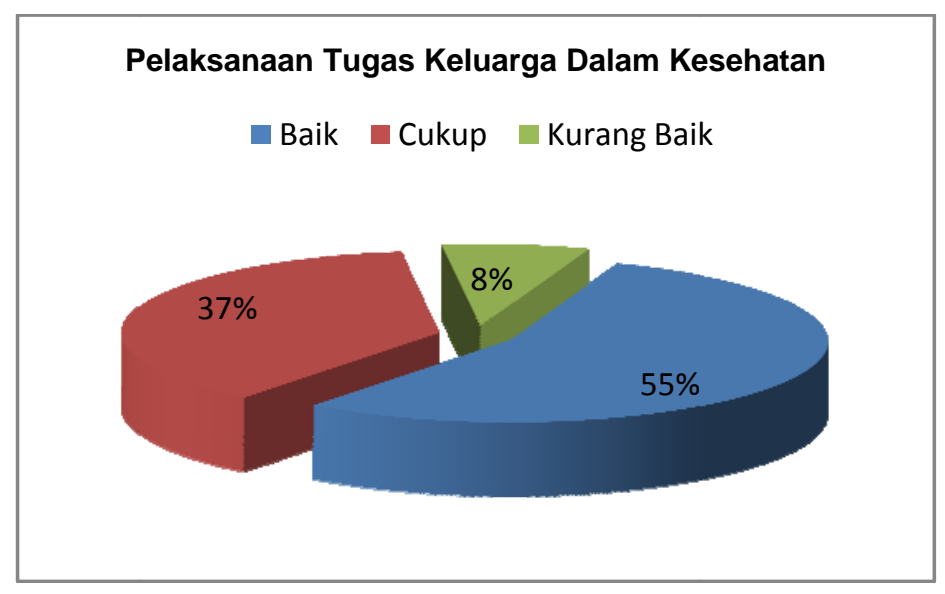

Gambar 1. Diagram Pie PelaksanaanTugas Keluarga Dalam Kesehatan

Gambar 1 menunjukkan bahwa sebagian besar responden berada pada pelaksanaan baik sebanyak 22 orang $(55 \%)$.

Tabel 1. Lima Tugas Keluarga Dalam Kesehatan

\begin{tabular}{|c|c|c|c|c|}
\hline \multirow{2}{*}{5 Tugas Keluarga Dalam Kesehatan } & \multicolumn{2}{|c|}{ Baik } & \multicolumn{2}{|c|}{ Kurang Baik } \\
\hline & $\mathbf{n}$ & $\%$ & $\mathbf{n}$ & $\%$ \\
\hline Mengenali masalah kesehatan pada lansia & 28 & 70 & 12 & 30 \\
\hline $\begin{array}{c}\text { Mengambil keputusan yang tepat saat } \\
\text { lansia sakit }\end{array}$ & 18 & 45 & 22 & 55 \\
\hline Memberikan perawatan pada lansia & 30 & 75 & 10 & 25 \\
\hline $\begin{array}{l}\text { Mempertahan-kan kondisi lingkungan yang } \\
\text { sehat }\end{array}$ & 28 & 70 & 12 & 30 \\
\hline Menggunakan fasilitas kesehatan & 33 & 82,5 & 7 & 17,5 \\
\hline
\end{tabular}

Berdasarkan tabel 1 menunjukkan bahwa distribusi lima tugas keluarga dalam kesehatan nilai tertinggi berada pada tugas menggunakan fasilitas kesehatan yaitu sebanyak 33 responden $(82,5 \%)$. 
Tabel 2. Aktivitas Kemandirian ADL Lansia

\begin{tabular}{lcccc}
\hline \multirow{2}{*}{ Aktivitas ADL } & \multicolumn{2}{c}{ Mandiri } & \multicolumn{2}{c}{ Bantuan } \\
\cline { 2 - 5 } & $\mathbf{n}$ & 32,5 & 27 & $\mathbf{0}$ \\
\hline Mandi & 13 & 92,5 & 3 & 7,5 \\
Berpakaian & 37 & 55 & 18 & 45 \\
Ke kamar kecil & 22 & 90 & 4 & 10 \\
Berpindah & 36 & 70 & 12 & 30 \\
Kontrol BAB \& BAK & 28 & 95 & 2 & 5 \\
Makan & 38 & & \\
\hline
\end{tabular}

Berdasarkan tabel 2 menunjukkan bahwa sebagian besar lansia mandiri pada aktivitas makan yaitu sebesar 38 orang (95\%).

ANALISA DATA

Tabel 3. Tabulasi Silang

\begin{tabular}{lcccccccc}
\hline \multirow{2}{*}{ Tugas Keluarga } & \multicolumn{9}{c}{ Kemandirian Lansia } & \multicolumn{2}{c}{ Total } \\
\cline { 2 - 7 } & $\mathrm{n}$ & $\%$ & $\mathrm{n}$ & $\%$ & $\mathrm{n}$ & $\%$ & $\mathrm{n}$ & $\%$ \\
\hline Baik & 22 & 55 & 0 & 0 & 0 & 0 & 22 & 55 \\
Cukup & 3 & 7,5 & 12 & 30 & 0 & 0 & 15 & 37,5 \\
Kurang & 0 & 0 & 1 & 2,5 & 2 & 5 & 3 & 7,5 \\
\hline Total & 25 & 62,5 & 13 & 32,5 & 2 & 5 & 40 & 100 \\
\hline
\end{tabular}

Tabel 3 didapatkan jumlah keluarga yang melaksanakan tugas keluarga dalam kesehatan kategori baik dengan kemandirian lansia kategori mandiri sebanyak 22 orang (55\%). Tingkat kemaknaan uji rank spearman pada penelitian ini menggunakan $P$-value $0,000<0,05$, maka $\mathrm{H}_{0}$ ditolak dan $\mathrm{H}_{1}$ diterima yang berarti ada hubungan yang signifikan antara dua variabel yaitu pelaksanaan tugas keluarga dalam kesehatan dengan kemandirian lansia dalam pemenuhan aktivitas sehari-hari (ADL). Pada kolom nilai koefisien korelasi di dapat hasil sebesar 0,817, ini menunjukkan ada hubungan yang sangat kuat dan koefisien korelasi bernilai positif, jadi dapat disimpulkan bahwa hubungan antara kedua variabel adalah searah dimana semakin baik pelaksanaan tugas keluarga dalam kesehatan, semakin tinggi kemandirian lansia dalam pemenuhan aktivitas sehari-hari.

\section{PEMBAHASAN}

\section{Pelaksanaan Tugas Keluarga Dalam Kesehatan}

Data pada variabel pelaksanaan tugas keluarga dalam kesehatan menunjukkan bahwa dari 40 responden yang diteliti didapatkan bahwa distribusi pelaksanaan tugas keluarga dalam kesehatan yaitu sebagian besar berada pada kategori pelaksanaan baik sebanyak 22 orang (55\%), pelaksanaan tugas keluarga dalam kesehatan pada kategori kurang sebanyak 3 orang $(7,5 \%)$. Sedangkan pada kelima tugas keluarga dalam kesehatan nilai tertinggi berada pada tugas menggunakan fasilitas kesehatan yaitu sebanyak 33 responden $(82,5 \%)$. Hal ini terjadi karena sebagian besar responden berusia dewasa tengah dengan rentang usia 40-59 tahun sebanyak 23 orang $(57,5 \%)$.

Menurut peneliti, usia sangat mempengaruhi pelaksanaan tugas keluarga dalam kesehatan. Hal ini dikarenakan pada usia dewasa tengah yang berada pada rentang usia 40-59 tahun ini dipenuhi tanggung jawab yang berat dan berbagai peran yang menyita waktu dan energi seperti menjalankan rumah tangga, mengembangkan usaha atau bisnis, memiliki anak dan bahkan memelihara atau merawat orang tuanya yang sudah lanjut usia. Selain itu, pada usia dewasa tengah ini hubungan antar generasi atau hubungan kedekatan anak dan orang tua tampak semakin meningkat. Hubungan kedekatan tersebut dapat dilihat pada lima tugas keluarga dalam kesehatan dimana nilai tertinggi terdapat pada tugas menggunakan fasilitas kesehatan. Hal ini dikarenakan jarak 
antara lokasi Dusun Bendungrejo dengan puskesmas cukup dekat yaitu sekitar $1 \mathrm{~km}$, dan pelayanan di puskesmas tersebut adalah 24 jam, sehingga keluarga dan lansia dapat berkunjung ke puskesmas dengan mudah jika sakit. Selain itu, di Dusun Bendungrejo juga terdapat posyandu lansia sehingga keluarga bisa mengantarkan lansia ke posyandu tersebut untuk memeriksakan kesehatannya.

Keluarga mempunyai peranan penting bagi kehidupan lansia, khususnya ketika terjadi perubahan-perubahan pada lansia yang meliputi fungsi fisik dan mental (Meiner \& Lueckonette, 2006). Dengan adanya perubahan-perubahan tersebut, keluarga harus bisa merawat lansia dengan baik. Fungsi perawatan kesehatan keluarga merupakan salah satu aspek dalam kehidupan keluarga, namun keluarga mempunyai perbedaan persepsi dan ide tentang sehat dan sakit, serta keputusan untuk mendiskusikan tentang masalah kesehatan yang dihadapi oleh lansia (Kaakinen, dkk, 2010). Hal ini akan membedakan keluarga dalam memberikan perawatan dan pelayanan kesehatan pada lansia.

Setiap keluarga mempunyai pola tersendiri dalam mengatasi masalah yang dihadapi oleh anggota keluarga termasuk masalah kesehatan pada lansia. Terkadang keluarga menyatakan telah melakukan tugas dengan baik dan telah memenuhi kebutuhan lansia sebagai anggota keluarga. Namun harus disadari bahwa lansia dengan penurunan fungsi yang dialami akan mengalami banyak perubahan yang tentunya membutuhkan perlakuan yang berbeda atau perlakuan yang spesifik sesuai dengan kondisi yang dialami.

Penelitian yang dilakukan Wiyono (2007) menyatakan bahwa, keluarga sangat membutuhkan pelayanan kesehatan, khususnya dalam hal pemeliharaan kesehatan lansia di rumah, keterjangkauan pelayanan yang dibutuhkan dan pelayanan yang dilakukan secara berkala sehingga dapat meningkatkan pelaksanaan tugas keluarga dalam kesehatan. Menurut Sahar (2004) bahwa keluarga yang memiliki tingkat pengetahuan dan keterampilan yang baik, maka akan memberikan perawatan yang baik pada lansia.

Berdasarkan hal tersebut berarti keluarga dengan pengetahuan yang cukup, akan melaksanakan tugas keluarga dalam kesehatan dengan baik. Pelaksanaan tugas kesehatan yang baik akan meningkatkan tingkat kemandirian lansia dalam pemenuhan ADL dan diharapkan keluarga dapat memberikan pelayanan yang maksimal pada lansia.

\section{Tingkat Kemandirian Lansia Dalam Memenuhi ADL}

Data pada variabel tingkat kemandirian lansia dalam pemenuhan ADL didapatkan hasil sebagian besar responden merawat lansia dengan tingkat kemandirian pada kategori mandiri yaitu sejumlah 25 orang $(62,5 \%)$ dan tingkat kemandirian lansia pada kategori bantuan total sejumlah 2 orang (5\%). Sedangkan, hasil pengukuran aktivitas kemandirian lansia dalam ADL didapatkan data nilai tertinggi terdapat pada kemampuan makan yaitu 38 lansia (95\%), dan nilai terendah pada kemampuan mandi yaitu 13 lansia (32,5\%).

Menurut peneliti, sebagian besar lansia mandiri dalam pemenuhan ADL disebabkan karena anggota keluarga sangat memperhatikan dan peduli dengan kondisi kesehatan lansia. Hal ini dibuktikan dengan kemampuan lansia pada aktivitas makan secara mandiri. Lansia akan merasa aman dan nyaman jika berada dekat dengan keluarganya. Akan tetapi pada poin pertama mengenai kemampuan mandi dari lansia didapatkan paling rendah karena faktor kemampuan fisik sangat berpengaruh terhadap kemampuan pemenuhan kebutuhan mandi pada lansia. Sehingga dalam kondisi ini menjadikan lansia sangat tergantung pada keluarga yang tinggal satu rumah dengan lansia tersebut.

Sesuai dengan teori dimana lanjut usia sebagai individu sama halnya dengan klien yang digambarkan oleh Orem (2001), yaitu suatu unit yang juga menghendaki kemandirian dalam mempertahankan hidup, kesehatan, dan kesejahteraannya. Penelitian ini juga didukung oleh penelitian Kobayashi (2009) yang menyatakan bahwa $64 \%$ responden lansia di institusi memiliki tingkat kemandirian yang tinggi dalam ADL. Berdasarkan hasil penelitian yang dilakukan oleh Suhartini (2004) di Kelurahan Jambangan Jawa Timur, menunjukkan bahwa sebagian besar responden mandiri dalam melaksanakan aktivitasnya yaitu $73,1 \%$. Kemandirian pada lanjut usia tergantung pada kemampuan status fungsionalnya dalam melakukan aktivitas sehari-hari. Faktor-faktor yang mempengaruhi kemandirian lansia adalah usia, imobilitas, mudah jatuh, dan kondisi kesehatan (Lueckenotte, 1996).

Pemberian asuhan keperawatan pada lansia yang sakit menjadi prioritas utama dalam mempertahankan kondisi kesehatan serta kemampuan mereka yang telah lansia dengan perawatan dan pencegahan. Berdasarkan hal tersebut, kondisi kesehatan lansia yang prima, maka kemandirian lansia juga semakin meningkat sehingga lansia dapat melakukan ADL secara mandiri. 


\section{Hubungan Pelaksanaan Tugas Keluarga Dalam Kesehatan dengan Kemandirian Lansia Dalam Memenuhi ADL}

Berdasarkan hasil penelitian didapatkan jumlah responden yang melaksanakan tugas keluarga dalam kesehatan kategori baik dengan kemandirian lansia kategori mandiri sebanyak 22 orang (55\%). Responden yang melaksanakan tugas keluarga dalam kesehatan kategori kurang baik dengan kemandirian lansia kategori sedang sebanyak 1 orang $(2,5 \%)$. Setelah dilakukan analisa antara pelaksanaan tugas keluarga dalam kesehatan dengan kemandirian lansia dalam pemenuhan ADL dengan menggunakan uji statistik Rank Spearman didapatkan bahwa Pvalue $0,000<0,05$ yang berarti $\mathrm{H}_{0}$ di tolak dan $\mathrm{H}_{1}$ diterima. Artinya ada hubungan antara pelaksanaan tugas keluarga dalam kesehatan dengan kemandirian lansia dalam pemenuhan ADL, dimana semakin baik pelaksanaan tugas keluarga dalam kesehatan semakin tinggi tingkat kemandirian dalam pemenuhan ADL.

Menurut peneliti, seorang anggota keluarga yang melaksanakan tugas keluarga dalam kesehatan dengan baik kepada lansia, pasti kondisi kesehatan lansia juga semakin baik. Dengan kondisi kesehatan lansia yang semakin baik, maka derajat kualitas hidup lansia juga akan semakin meningkat. Peningkatan kualitas hidup lansia dapat dilihat dari tingkat kemandirian lansia dalam melakukan aktivitas sehari-hari. Hal ini disebabkan keluarga merupakan orang yang paling dekat dengan lansia. Sehingga lansia akan merasa nyaman ketika berada di dekat keluarganya. Jika kompetensi keluarga dalam melaksanakan tugas keluarga di bidang kesehatan sangat baik, maka tingkat kemandirian lansia dalam memenuhi aktivitas sehari-hari juga semakin membaik atau dengan kata lain lansia tidak membutuhkan bantuan orang lain.

Proses perkembangan lansia dapat dipengaruhi oleh berbagai stressor seperti faktor penuaan atau aging process yang dialami lansia serta kompetensi keluarga dalam melaksanakan tugas di bidang kesehatan. Tugas keluarga pada lansia (Friedman, 1998 dalam Mubarak, 2006) meliputi mengenali masalah kesehatan pada lansia, membuat keputusan tindakan kesehatan yang tepat pada lansia, memberi perawatan pada lansia yang sakit, mempertahankan atau menciptakaan suasana rumah yang sehat, dan menggunakan fasilitas kesehatan yang tersedia. Dalam hal ini, keluarga mempunyai peranan penting bagi kehidupan lansia, khususnya ketika terjadi perubahan-perubahan pada lansia yang meliputi fungsi fisik dan mental (Meiner \& Lueckonette, 2006).
Perubahan-perubahan pada lansia umumnya mengarah pada kemunduran kesehatan fisik (fungsi organ) dan psikis, yang pada akhirnya akan berpengaruh juga pada aktivitas ekonomi dan sosial mereka. Sehingga kemunduran fisik dan psikis tersebut menyebabkan lansia menjadi terbatas dalam melakukan aktivitasnya dan cenderung tergantung dengan orang lain (Nugroho, 2008). Ketergantungan yang paling nyata adalah ketergantungan lansia dalam memenuhi aktivitas sehari-hari (activity of daily living).

Ketergantungan lansia yang semakin meningkat membuktikan bahwa derajat kesehatan lansia menurun serta akan mempengaruhi kualitas hidup lansia tersebut. Dalam kondisi ini, lansia seharusnya mendapat perhatian dari seluruh kalangan baik dari keluarga, masyarakat, maupun tenaga kesehatan terutama untuk meningkatkan kualitas hidupnya, karena kualitas hidup lansia bisa dikatakan baik jika kesehatan fisik, psikologis, dan sosialnya baik.

\section{KETERBATASAN PENELITIAN}

Desain penelitian ini menggunakan study cross sectional sehingga hasil pengukuran hanya dilakukan satu kali pada saat itu saja tanpa memperhatikan faktor-faktor lain yang dapat mempengaruhi seperti kondisi lingkungan keluarga. Sedangkan, pengambilan data hanya dilakukan dengan menggunakan kuesioner tanpa melakukan observasi perilaku keluarga terhadap lansia atau observasi langsung pada lansia, sehingga akan memunculkan persepsi responden. Penelitian ini tidak memungkinkan dilaksanakan observasi karena keterbatasan waktu penelitian.

\section{KESIMPULAN}

Berdasarkan hasil penelitian dapat disimpulkan sebagai berikut : Ada hubungan yang sangat kuat antara pelaksanaan tugas keluarga dalam kesehatan dengan kemandirian lansia dalam pemenuhan aktivitas sehari-hari, dimana semakin baik pelaksanaan tugas keluarga dalam kesehatan semakin baik pula tingkat kemandirian lansia dalam pemenuhan ADL. Pelaksanaan tugas keluarga baik yaitu pada tugas menggunakan fasilitas kesehatan. Tingkat kemandirian lansia dominan tingkat mandiri yaitu dalam aktivitas makan.

\section{SARAN}

Penelitian selanjutnya perlu dikaji terkait faktor berpengaruh terhadap pelaksanaan tugas keluarga dalam kesehatan 
dengan kemandirian lansia dalam pemenuhan ADL seperti faktor lingkungan keluarga dengan metode observasi. Serta pelibatan keluarga dalam penyuluhan dan promosi kesehatan tentang kesehatan lansiasebagai upaya meningkatkan pengetahuan dan keterampilan cara merawat lansia serta meningkatkan

\section{DAFTAR PUSTAKA}

Bandiyah, Siti. 2009. Lanjut Usia dan keperawatan Gerontik. Yogyakarta : Nuha Medika.

Efendy, Ferry dan Makhfudi. 2009. Keperawatan Kesehatan Komunitas : Teori dan Praktik dalam Keperawatan. Jakarta : Penerbit Salemba Medika.

Effendi, S. 2006. Perubahan Struktur Keluarga dalam Perspektif Pencapaian Keluarga Sejahtera. Dalam Dwiyanto, A., Faturochman, Molo, M. \& Abdullah, I. (eds). Penduduk dan Pembangunan. Yogyakarta : Aditya Media.

Fatmah. 2010. Gizi Usia Lanjut. Jakarta : Erlangga.

Kaakinen, J.R. et al., 2010. Family Health Care Nursing : Theory Practice and Research (Fourth Edition). Philadelphia: T.A Davis Company.

Kobayashi, N., Nurviyandari, D., Yamamoto, M., Sugiyama, T., Sugai, Y., 2009. Severity of Dementia as a Risk Factor For Repeat Falls among the institutionalized elderly in Japan. Journal of Nursing and Health Science. 11 (3) 388-396.

Kuczynski, B, Jagust, W, Chui, HC., Reed, B 2009, "An Inverse Association of Cardiovascular Risk and Frontal Lobe Glucose Metabolism", Neurology, vol. 72, hal. 738-743.

Maryam RS, dkk. 2008. Mengenal Usia Lanjut dan Perawatannya. Jakarta : Salemba Medika.

Meiner, S.E., \& Lueckonette, G.E. 2006. Gerontologic Nursing (Third Edition). St. Louis: Mosby Elsevier

Mubarak, WI., BA. Santoso, K. Rozikin, S. Patonah. 2006. Buku Ajar IImu Keperawatan Komunitas 2. Jakarta : CV. Sagung Seto

Nugroho, Wahjudi. 2000. Keperawatan Gerontik. Jakarta: EGC

Nugroho, W. 2008, Keperawatan Gerontik dan Geriatrik. Jakarta : EGC pemahaman terhadap tugas-tugas keluarga dalam rangka pemeliharaan kesehatan pada lansia. Lansia terus meningkatkan kemampuan ADL dengan cara mengikuti penyuluhan kesehatan dan secara teratur mengunjungi posyandu lansia.

Nursalam. 2003. Konsep dan Penerapan Metodologi Penelitian IImu Keperawatan. Jakarta : Salemba

Orem, D. E., 2001. Nursing : Concept of Practice. (6th Ed.). St. Louis : Mosby Inc.

Parker, D. K. 2005. Menumbuhkan Kemandirian dan Harga Diri Anak. Jakarta : Prestasi Pustakarya.

Potter, dan Perry. 2005. Buku Ajar Fundamental Keperawatan : Konsep, Proses, dan Praktik Vol. 1 (Edisi 4). Cet. Pertama. Jakarta : EGC

Potter, dan Perry. 2009. Fundamental Keperawatan Buku 1 Edisi 7. Jakarta: Salemba Medika

Primadi, Oscar. 2013. Gambaran usia Lanjut di Indonesia . Buletin Jendela Data dan Informasi Kesehatan. Pusat Data dan Informasi Kementerian Kesehatan RI.

Pudjiastuti, Sri Surini \& Budi Utomo. 2003. Fisioterapi pada Lansia. Jakarta : Penerbit Buku Kedokteran EGC.

Sahar, J. 2004. Improvement of family carers knowledge, skill, and attitude in caring for older people following the implementation of a family carers training program in the community in Indonesia. International Journal of Nursing Practice, 9 (4) 246-254.

Santoso, Hana dan Andar Ismail. 2009. Memahami Krisis Usia Lanjut : Uraian Medis dan Pedagogis Pastoral. Jakarta : Gunung Mulia.

Setiadi, 2008. Keperawatan Keluarga. Jakarta : Buku Kedokteran EGC.

Setiati, Siti. 2000. Pedoman Praktis Perawatan Kesehatan Untuk Mengassuh Orang Usia Lanjut. Jakarta : PKUI

Shelkey, Mary, dkk. 2012. Katz Index of Independence in Activities of Daily Living (ADL). Best Practice in Nursing Care to Older Adults. Diakses 25 November 2014.

Suhartini R. 2009. Hubungan Status Kesehatan, Ekonomi, dan Sosial Terhadap Kemandirian Lanjut Usia. Surabaya: Universitas Airlangga. 
164 | J.K.Mesencephalon, Vol.3 No.3, April 2018, hlm 158-164

Suhartini R. 2004. Faktor-faktor Yang mempengaruhi Kemandirian Lanjut Usia: Studi Kasus di Kelurahan Jombangan Tahun 2004. http://www.damandiri.or.id. Diakses, 2 Maret 2015

Suyono, Slamet. 2001. Buku Ajar IImu Penyakit Dalam Jilid II Edisi Ketiga. Jakarta : Balai Penerbit FKUI.

S.Tamher, Noorkasiani. 2009. Kesehatan Usia Lanjut dengan Pendekatan Asuhan Keperawatan. Jakarta : Salemba Medika
Wiyono, J. 2007. Pengalaman keluarga Dalam Merawat lansia Dengan Tingkat Ketergantungan Tinggi Di Rumah Kota malang Jawa Timur : Studi Fenomenologi. Tesis tidak dipublikasi, FIK Universitas Indonesia, Depok. 